\title{
Volatile Compounds, Sensory Profile and Phenolic Compounds in Fermented Rice Bran
}

\author{
Ardiansyah ${ }^{1, *(D)}$, Annisa Nada ${ }^{1}$, Nuraini Tiara Indah Rahmawati ${ }^{1}$, Annisa Oktriani ${ }^{1}$, Wahyudi David ${ }^{1}$, \\ Rizki Maryam Astuti ${ }^{1}$, Dody Dwi Handoko ${ }^{2}$, Bram Kusbiantoro ${ }^{2}$, Slamet Budijanto ${ }^{3}$ and Hitoshi Shirakawa 4,5 (D)
}

1 Department of Food Technology, Universitas Bakrie, Jakarta 12920, Indonesia; nadannisa@gmail.com (A.N.); nuraini.tiara@gmail.com (N.T.I.R.); annisa.oktriani@gmail.com (A.O.); wahyudi.david@bakrie.ac.id (W.D.); rizki.astuti@bakrie.ac.id (R.M.A.)

2 Laboratory of Flavor Analysis, Indonesian Center for Rice Research, Indonesian Agency for Agricultural Research and Development, Ministry of Agriculture, Subang, Jawa Barat 41256, Indonesia; dodyhandoko@gmail.com (D.D.H.); hbram_kusbiantoro@yahoo.com (B.K.)

3 Department of Food Science and Technology, Faculty of Agricultural Engineering and Technology, IPB University, Bogor 16680, Indonesia; slametbu@apps.ipb.ac.id

4 Laboratory of Nutrition, Graduate School of Agricultural Science, Tohoku University, 468-1 Aramaki Aza Aoba, Aoba-ku, Sendai 980-8572, Japan; shirakah@tohoku.ac.jp

5 International Education and Research Center for Food Agricultural Immunology, Graduate School of Agricultural Science, Tohoku University, Sendai 980-8572, Japan

* Correspondence: ardiansyah.michwan@bakrie.ac.id; Tel.: +62-21-5261448 (ext. 208); Fax: +62-21-5263191

\section{check for} updates

Citation: Ardiansyah; Nada, A.; Rahmawati, N.T.I.; Oktriani, A.; David, W.; Astuti, R.M.; Handoko, D.D.; Kusbiantoro, B.; Budijanto, S.; Shirakawa, H. Volatile Compounds, Sensory Profile and Phenolic Compounds in Fermented Rice Bran. Plants 2021, 10, 1073. https:// doi.org/10.3390/plants10061073

Academic Editors: Lina Raudone and Nijole Savickienè

Received: 6 May 2021

Accepted: 22 May 2021

Published: 27 May 2021

Publisher's Note: MDPI stays neutral with regard to jurisdictional claims in published maps and institutional affiliations.

Copyright: (c) 2021 by the authors. Licensee MDPI, Basel, Switzerland. This article is an open access article distributed under the terms and conditions of the Creative Commons Attribution (CC BY) license (https:/ / creativecommons.org/licenses/by/ $4.0 /)$.

\begin{abstract}
Rice bran (RB), a by-product of the rice milling process, is a rich source of bioactive compounds. Current studies have suggested that fermentation can enhance the bioactivities of RB. This study is aimed to analyse the volatile compounds and sensory profile of fermented RB from two cultivars (Inpari 30 and Cempo Ireng) that are well-known in Indonesia, as well as to measure total phenolic content (TPC) and antioxidant activity. Volatile compounds of fermented RB were analyzed using gas chromatography-mass spectrometry combined with headspace-solid phase microextraction. The optimum TPC and antioxidant activity were observed after $72 \mathrm{~h}$ fermentation of RB. The 55 volatile compounds were identified in fermented and non-fermented RB. They were classified into alcohols, aldehydes, acids, ketones, phenols, esters, benzene, terpenes, furans, lactone, pyridines, pyrazines, and thiazoles. Volatile compounds were significantly different among the varieties. The sensory analysis showed that the panelists could differentiate sensory profiles (color, taste, flavor, and texture) between the samples. Fermentation can enhance the acceptance of RB. These studies may provide opportunities to promote the production of fermented RB as a functional ingredient with enhanced bioactivity for health promotion.
\end{abstract}

Keywords: antioxidant activity; fermented rice bran; rice bran; sensory profile; volatile compounds

\section{Introduction}

Rice has been cultivated in the South East Asia region, including Indonesia, since 2500 B.C. [1]. There are several varieties of rice in Indonesia such as aromatic, non-aromatic, and pigmented. Indonesia produced around 54.60 million metric tons of rice in 2019 [2]. Polished rice is the major product of the rice milling process, with $8-12 \%$ being the byproduct rice bran $(\mathrm{RB})$; around 5.5 million metric tons of $\mathrm{RB}$ were produced in the same year.

$\mathrm{RB}$ is a by-product of rice milling, sitting between the between endosperm and the outer layer of rice. $\mathrm{RB}$ has received much attention because it contains diverse active compounds that have a broad spectrum of health benefits [3-6]. These properties are ascribed to the high amounts of total flavonoid, tocopherols, tocotrienols, $\gamma$-oryzanol, and total phenolic content (TPC) $[7,8]$. Phenolic compounds are key compounds in antioxidant activities due to their capacity to scavenge free radicals, disrupt radical chain reactions, and chelate metal ions [9]. In some pigmented rice cultivars, the pigment is concentrated in 
the outer layer of the rice grain. Pigments in the outer layers are responsible for the color of some rice cultivars which are referred to as pigmented cultivars. In Indonesia, pigmented rice is classified into black and red rice.

Solid-state fermentation (SSF) using microorganisms and their enzymes is one of the beneficial strategies to increase bioactive compounds in plant foods [10]. SSF is effective at increasing TPC, antioxidant activity, and organic acid [11-13]. The activity of the enzyme $\beta$-glucosidase in fungi increases hydroxyl compounds that increase free phenolic compounds in RB [14]. Recently, our groups' studies have shown that SSF with Rhizopus oligosporus can induce enzyme activity that could also lead to the release of phenolic compounds, higher antioxidant activity, blood pressure lowering activity in stroke-prone spontaneously hypertensive rats, anti- $\alpha$-amylase activity, and antiproliferative properties toward colon cancer in WiDr cell lines [15-17].

Volatile compounds are chemicals that play a key role in the formation of aromas in food products. The volatile compounds of RB have been reported by several investigators. They have used gas chromatography-mass spectrometry (GC-MS) to identify the compounds. The identified compounds of RB consist of alcohol, alkanes, ketones, and aldehydes [18-20]. Hexanal is a common compound in RB that may cause off-odor in RB because of enzyme activity during processing of RB [21,22]. Another report has shown that volatile compounds of black RB consist of aldehyde, alcohol, alkenes, and ketone [21]. Current data shows that volatile compounds of fermented RB by different lactic acid bacteria were acids, aldehydes, esters, furan derivatives, ketones, alcohols, benzene and benzene derivatives, hydrocarbons, and terpenes [23]. Furthermore, when RB was fermented by Lactobacillus paracasei, it produced some volatile compounds, especially lactones, 2,3-butanedione, and 3-hydroxy-2-butanone, which are similar to a compound in dairy products (i.e., cheese, fermented milk, and butter). These can improve the sensory profile of rice-based probiotic functional foods [24,25].

This is the first study to investigate the formation of volatile compounds in Indonesian fermented RB. The objective of this study was to analyze the profiles of volatile compounds of two cultivars of RB in Indonesia as well as TPC and antioxidant activity. Inpari 30 (IPR30) cultivar is one of the Ciherang cultivars (white rice) that is most widely consumed in Indonesia. Cempo Ireng (CI) black rice is one of the local pigmented rice varieties in Indonesia and has a high content of phenolics, total flavonoids, and total anthocyanins [16]. In this study, new methods have been also developed to identify the sensory profile of fermented RB using projective mapping (napping) methods. Napping is a fast sensoryanalysis method based on the spontaneous placement of products by panelists conducted in two dimensions by grouping the same attributes [26].

\section{Results}

\subsection{Total Phenolic Content and Antioxidant Activity}

The TPC was significantly higher $(p<0.05)$ in both fermented RB after 72 and $96 \mathrm{~h}$ of fermentation than in non-fermented RB (0 h) (IPR30; $1.57 \pm 0.19$ and CI; $6.12 \pm 0.70 \mathrm{mg}$ GAE/g dry basis (DB), respectively. However, fermentation for $24 \mathrm{~h}$ is not sufficient to increase the TPC of fermented RB (Table 1). The highest TPC was obtained at $72 \mathrm{~h}$ fermentation of IPR30 and CI fermented RB $(2.24 \pm 0.21$ and $7.85 \pm 0.62 \mathrm{mg} \mathrm{GAE} / \mathrm{g} \mathrm{DB}$, respectively (Table 1 ).

The fermentation process significantly increased in $(p<0.05)$ the DPPH RSA of both cultivars, with the highest RSA observed after $96 \mathrm{~h}$ of fermentation at the level $69.50 \pm 1.53 \%$ and $48.12 \pm 2.84 \%$, respectively (Table 1 ). However, prolonging of the incubation time until $96 \mathrm{~h}$ was not significantly different when compared with $72 \mathrm{~h}$ of fermentation of RSA and TPC, respectively; then, we decided to use both varieties with $72 \mathrm{~h}$ fermentation for further analyses. 
Table 1. Total phenolic content (TPC) and DPPH radical scavenging activity (RSA) of RB.

\begin{tabular}{ccccc}
\hline \multirow{2}{*}{$\begin{array}{c}\text { Incubation } \\
\text { Time (h) }\end{array}$} & \multicolumn{2}{c}{ IPR30 } & \multicolumn{2}{c}{ CI } \\
\cline { 2 - 5 } & TPC & DPPH RSA & TPC & DPPH RSA \\
\hline 0 & $1.57 \pm 0.19^{\mathrm{a}}$ & $0.94 \pm 0.13^{\mathrm{a}}$ & $6.12 \pm 0.70^{\mathrm{a}}$ & $9.22 \pm 0.77^{\mathrm{a}}$ \\
48 & $1.96 \pm 0.02^{\mathrm{ab}}$ & $1.21 \pm 0.66^{\mathrm{b}}$ & $6.10 \pm 0.53^{\mathrm{a}}$ & $5.27 \pm 0.03^{\mathrm{b}}$ \\
72 & $2.24 \pm 0.21^{\mathrm{b}}$ & $1.46 \pm 0.14^{\mathrm{bc}}$ & $7.85 \pm 0.61^{\mathrm{b}}$ & $10.37 \pm 0.82^{\mathrm{ac}}$ \\
96 & $2.18 \pm 0.28^{\mathrm{b}}$ & $1.80 \pm 0.05^{\mathrm{c}}$ & $7.34 \pm 0.72^{\mathrm{b}}$ & $11.74 \pm 0.84^{\mathrm{c}}$ \\
\hline
\end{tabular}

TPC are expressed as [mg of gallic acid equivalents (GAE)/g DB and DPPH radical scavenging activity (RSA) are expressed as $\mathrm{mg}$ Trolox equivalent (TE) per $100 \mathrm{~g}$ of sample DB. Values are given as the means $\pm \mathrm{SD}, \mathrm{n}=4$ Means with the different letters within column are significantly different $(p<0.05)$ followed by Duncan's multiple range test.

\subsection{Volatile Compounds of Rice Bran}

The volatile compounds of fermented and non-fermented RB of IPR30 and CI were shown in Table 2. The 55 identified volatile compounds consisted of 13 alcohols, 11 aldehydes, 6 acids, 5 ketones, 4 phenols, 4 esters, 2 benzene, 3 terpenes, 2 furans, 2 lactones, 1 pyridine, 1 pyrazine, and 1 thiazole. The alcohol compounds were the most volatile compounds that were detected in both RB varieties (fermented and non-fermented), followed by aldehydes, acids, ketones, phenols, esters, benzenes, terpenes, furans, pyridines, and thiazole (Figure 1).

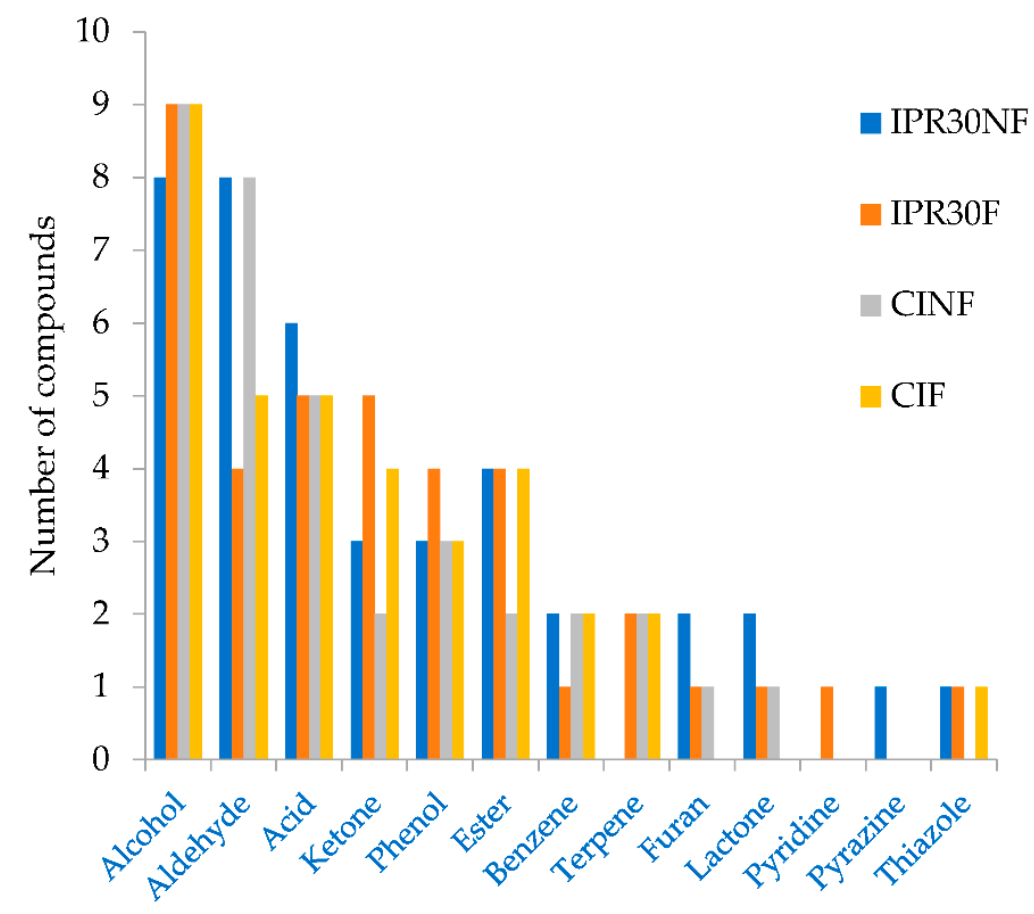

Figure 1. Groups of volatile compounds in fermented or non-fermented rice brans. Inpari 30 nonfermented (IPR30NF); Inpari 30 fermented (IPR30F); Cempo Ireng non fermented (CINF); and Cempo Ireng fermented (CIF).

The present study applied principal component analysis (PCA) to compare the differences and identify dominant volatile compounds among the fermented and non-fermented RB. The PCA plot of volatile compounds in Figure 2 shows RB with fermentation and without fermentation located in different dimensions. It shows that the fermentation process can affect the volatile compounds of RB. 
(a)

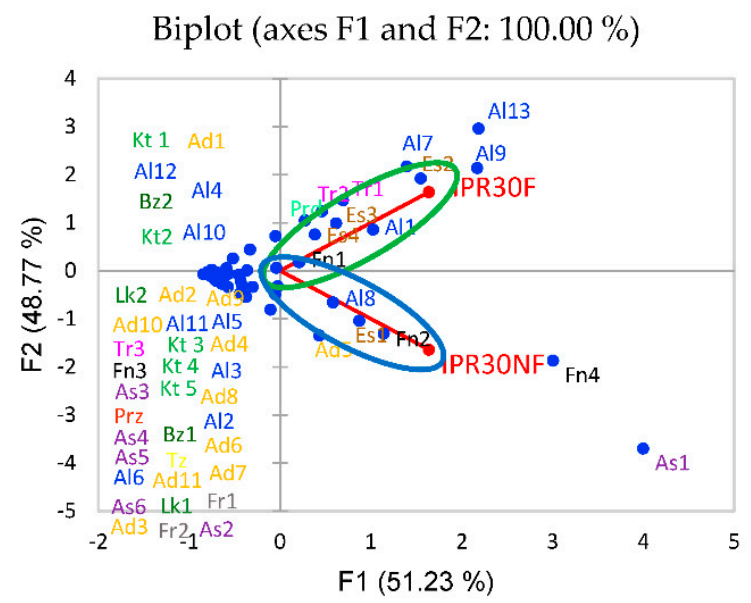

- Active variables - Active observations (b)

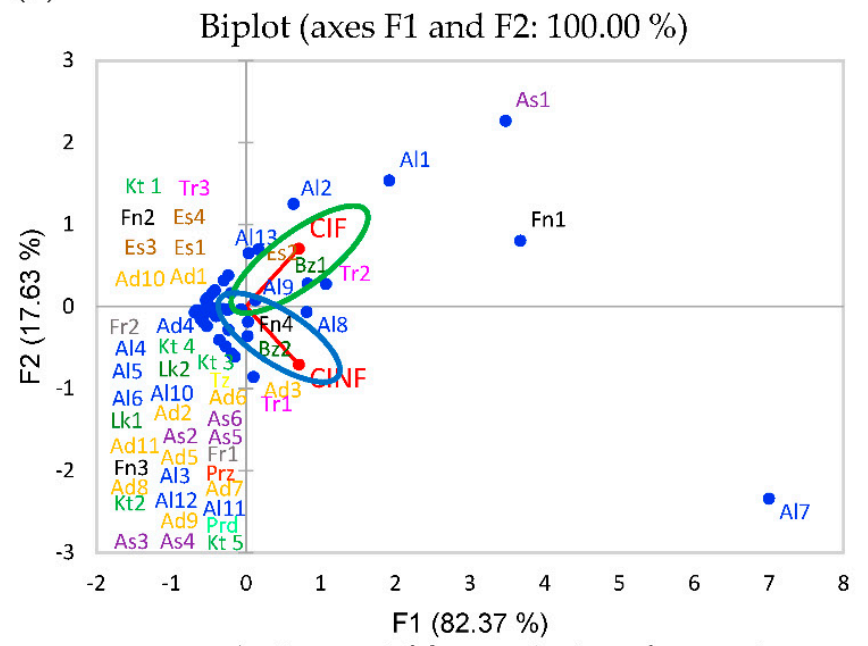

- Active variables - Active observations

Figure 2. PCA plot of volatile compounds of (a) Inpari 30 (IPR30) and (b) Cempo Ireng (CI) (F, fermented; NF, non-fermented).

Volatile compounds of IPR30 fermented RB were dominated by 3-methylbut-3-en-1-ol; 2,3-butandiol; benzylalcohol; glycerin; methyl hexadecanoate; (E)-9-methyl octadecanoate; (Z, Z) -9,12-methyl octadecadienoate; 1R-alpha-pinene; caryophyllene; 2-methoxyphenol; and 3-methyl pyridine. Most of these compounds were formed from lipid oxidation through enzymes activity in the mold that was used as the starter of fermentation. During the sterilization process in preparation of RB before fermentation, 2-Methoxyphenol and 3-methylpyridine were formed as a product of the Maillard reaction. These compounds contributed to sweaty, creamy, fatty, pungent, and smoky aromas. Conversely, IPR30 non-fermented RB was dominated by 2-furanmetanol; nonanal; methyl tetradecanoate; phenol; and 4-ethenyl-2-methoxyphenol (Figure 2a). These compounds contributed to burnt, nutty, and fatty aromas.

Meanwhile, the volatile compounds of CI fermented RB were dominated by 4-methyl3-penten-1-ol; benzyl alcohol; glycerin; methyl hexadecanoate; ethylbenzene; and caryophyllene. Most of these compounds were formed by hydrolysis of fatty acids in RB through enzyme activity in the mold that was used as the starter for fermentation. Furthermore, CI non-fermented RB was dominated by 2-furanmetanol; hexanal; naphthalene; 1R-alphapinene; and 4-ethenyl-2-methoxyphenol (Figure 2b) that contributed to burnt, nutty, fatty, and pungent aromas.

\subsection{Sensory Profile of Rice Bran}

A hierarchical clustering map was calculated based on the distance between the samples. The samples with a close distance were grouped as the same cluster. Figure 3a showed that there were two clusters. The first cluster consisted of samples 192 and 736; both samples were derived from CI fermented and non-fermented RB, respectively. The second cluster consisted of samples 298, 375, and 534. These samples, clustered into a single group, were derived from Inpari 30 fermented RB, Inpari 30 non-fermented RB, and benchmark, respectively. 
(a)

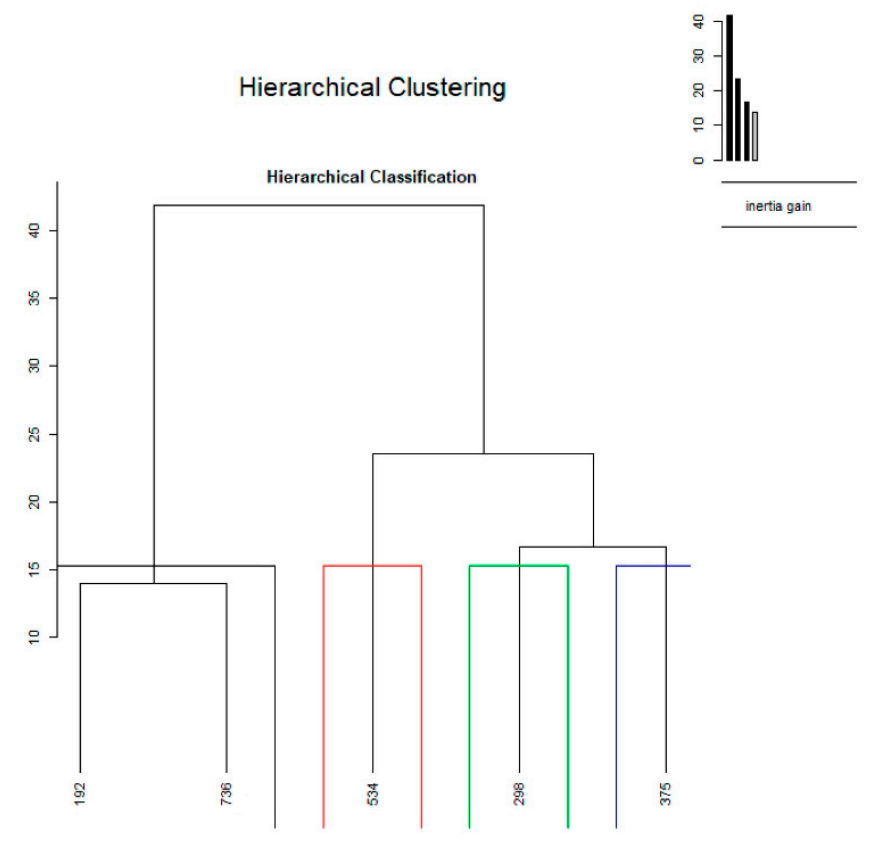

(b)

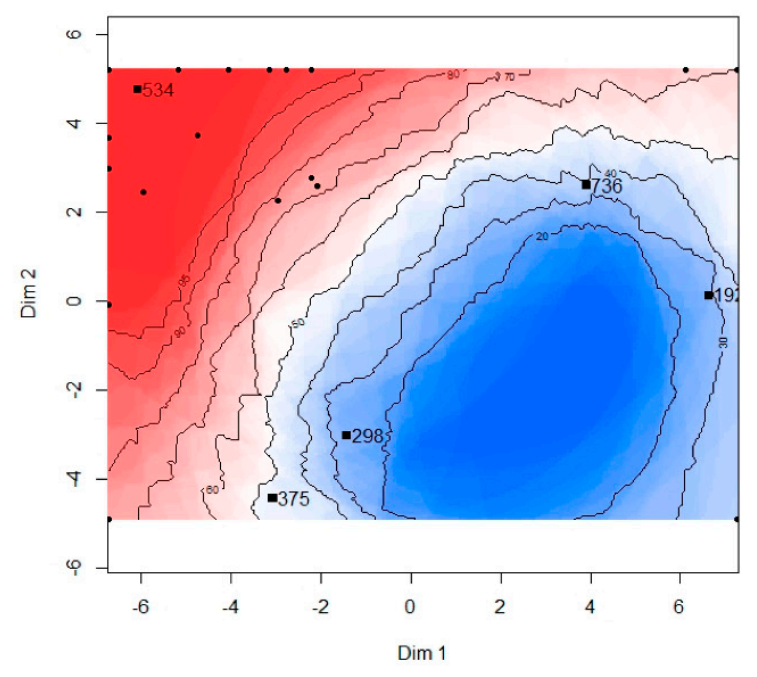

Sample elevation: (534: $\left.95^{\circ}\right)$; $\left(375: 40-50^{\circ}\right)$; $\left(298: 20-30^{\circ}\right) ;\left(736: 40^{\circ}\right) ;\left(192: 30^{\circ}\right)$

(c)

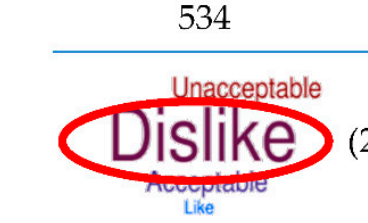

Like
(26)

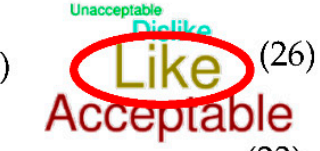

(23)
375

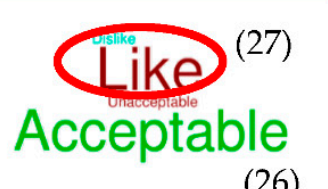

(26)

192

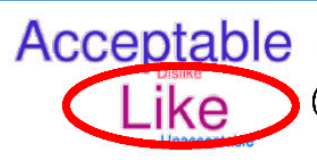

$(28)$

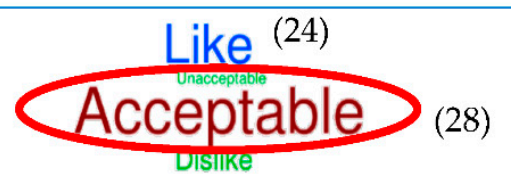

Figure 3. (a) Hierarchical Clustering Map; (b) Preference Mapping; and (c) Overall Acceptance (frequency panelist) of fermented and non-fermented rice bran. 534: Benchmark (Control), 192: CIF, 736: CINF, 298: IPR30F, and 375: IPR30NF.

Enhancing knowledge of consumer preference, we continued to analyze preference mapping of RB as shown in Figure 3b. The overall liking of the samples and sensory experiences has an important factor that contributes to consumers' buying expectations and decisions to buy products in the market. The data of overall acceptance $(n=75)$ of fermented and non-fermented RB are shown in Figure 3c.

\section{Discussion}

Phenolic compounds are widely found in plant products and they have antioxidant properties [10]. Our results showed that an increase in RSA was related to an increase in TPC, suggesting that TPC is responsible for antioxidant activities. Rhizopus oligosporus have been reported to be able to produce enzymes such as $\beta$-glucosidase, amylase, cellulase, chitinase, inulinase, phytase, xylanase, tanase, esterase, invertase or lipase that can enhance bran cell wall degradation, thus producing more free phenolic compounds. In addition, several studies have reported that phenolic acids, flavonoids, anthocyanins and others also contribute to the antioxidant activity of RB [27-29]. Another study showed that during 
fermentation, there was an increase in the content of chlorogenic acid, p-hydroxybenzoic acid, gallic acid, and ferulic acid vanillin in RB [10].

In this study, ethanol was significantly higher in most of the fermented RB. Ethanol is mainly formed from the fermentation process, and is derived from pyruvate through acetyl-CoA, whereas it is derived from the pentose phosphate pathway of glucose [23]. 3-methyl-3-buten-1-ol and 2-ethyl-1-hexanol contribute to sweaty, fruity, citrus, and oily aromas, respectively. Linalool was only found in CI non-fermented RB and contributed to citrus, greeny, and waxy aromas. Benzyl alcohol are formed via reduction of benzoic acid during fermentation through the glycolysis pathway [30] was higher in fermented RB. Phenylethyl alcohol are formed via hydrolysis of phenylethyl acetal and phenylethyl ester contributed to aroma floral and slightly rose [31,32]. Eugenol was found in all samples of fermented and non-fermented RB. Eugenol contributed to a sweet, clove-like, green aroma [33]. 2,3-butandiol, 3-methyl-3-butenol, benzyl alcohol and 2-furanmetanol are the main alcohol compounds and were formed in both IPR30 and CI fermented RB, including in CI non-fermented RB.

Acids are formed through the pentose phosphate pathway and the TCA cycle [34]. Furthermore, the acid group in this study was probably derived from aldehyde oxidation and lipid hydrolysis [35]. The present study showed that acetic acid produced a sour aroma in RB (Table 2). Hexanoic and octanoic acids contributed to sweaty and cheesy aromas (Table 2), while nonanoic acid contributed to greeny and fatty aromas (Table 2) [22,36]. The relative area of acetic acid is seen at higher levels in IPR30 non-fermented and CI fermented RB (Table 2). Acetic acid is also known to originate from the oxidation of acetaldehyde [34].

Ketones were detected in fermented RB, such as butenone, 4-hydroxybutan-2-one, 1-(1H-pyrrol-2yl) ethanone, 2-pyrrolidinone, and 6,10,14-trimethyl-2-pentadecanone. Ketones can give a pleasant aroma [37]. They can produce caramel, nutty, walnut, bready, oily, and herby aromas (Table 2), and are formed from fatty acids by enzymatic oxidative decarboxylation [21,22].

Esters, which have a fatty, waxy, and oily aroma (Table 2), are formed by esterification between alcohols and acids in fermentation [22]. The current study determined four esters, methyl tetradecanoate, hexadecanoic acid methyl ester, methyl (E)-octadec-9-enoate, and methyl (9Z,12Z)-octadeca-9,12-dienoate, in the fermented RB samples (Table 2), although they were present at low concentrations. The compounds of methyl (E)-octadec-9-enoate, and methyl (9Z,12Z)-octadeca-9,12-dienoate were not detected in CI non-fermented RB.

An interesting finding of the present study was that 2-pentylfuran, which has a greeny, beany, and buttery aroma (Table 2), has been reported as one of the odor-active compounds in various rice cultivars [22]. This compound was only detected in non-fermented IPR30. 2-methoxyphenol was significantly higher in CI RB (fermented and non-fermented) than IPR30 (Table 2), which contributes to the aroma in black rice [20].

We found that both samples 192 and 736 (Cempo Ireng fermented and Cempo Ireng non-fermented RB) were located in one cluster and have similar characteristics in taste attributes (savory, sweet, and salty), color attributes (black), and aroma attributes (fresh and milk) (Figure 3a); however, even though they have similar characteristic, 192 and 736 have a different elevation value of preference (Figure $3 b$ ). The second cluster consists of samples 298, 375, and 534 (Inpari 30 fermented, non-fermented, and benchmark, respectively) which were clustered into single group because they have similar characteristics in taste attributes (sweet, bitter, and savory), color attributes (yellow), and aroma attributes (fresh, milk, and rice). 
Table 2. Volatile compounds identified in fermented and non-fermented RB of IPR30 and CI.

\begin{tabular}{|c|c|c|c|c|c|c|c|c|}
\hline \multirow{3}{*}{ Compounds } & \multirow{3}{*}{ Code } & \multirow{3}{*}{$\begin{array}{c}\text { LRI } \\
\text { Experiment }\end{array}$} & \multirow{3}{*}{$\begin{array}{c}\text { LRI } \\
\text { Reference }\end{array}$} & \multicolumn{4}{|c|}{ Relative Peak Area $(\mu \mathrm{g} / \mathrm{kg})$} & \multirow{3}{*}{$\begin{array}{c}\text { Aroma } \\
\text { Description }\end{array}$} \\
\hline & & & & \multicolumn{2}{|c|}{ IPR30 } & \multicolumn{2}{|c|}{ CI } & \\
\hline & & & & Non-Fermented & Fermented & Non-Fermented & Fermented & \\
\hline \multicolumn{9}{|c|}{ Alcohols } \\
\hline 3-methyl-3-buten-1-ol & Al1 & 1252 & $1255[36]$ & $0.007 \pm 0.0038^{\mathrm{a}}$ & $0.03 \pm 0.013^{b c}$ & $0.012 \pm 0.005^{\mathrm{ab}}$ & $0.07 \pm 0.018^{c}$ & sweet, fruity [38] \\
\hline 4-methyl-3-penten-1-ol & $\mathrm{A} 12$ & 1392 & 1478 [39] & nd & nd & nd & $0.044 \pm 0.005$ & \\
\hline 2-butoxyethanol & $\mathrm{Al} 3$ & 1409 & $1379[40]$ & $0.003 \pm 0.0029$ & nd & nd & nd & \\
\hline Linalool & $\mathrm{Al} 5$ & 1551 & $1553[42]$ & nd & nd & $0.003 \pm 0.0007$ & nd & waxy, citrus, greeny [43] \\
\hline 1-Octanol & $\mathrm{Al} 6$ & 1564 & 1565 [42] & $0.007 \pm 0.0018$ & nd & $0.003 \pm 0.001$ & nd & fatty [43] \\
\hline 2,3-Butadienol & $\mathrm{Al} 7$ & 1584 & $1581[44]$ & nd & $0.048 \pm 0.051$ & $0.12 \pm 0.018$ & $0.09 \pm 0.07$ & butter, creamy [41] \\
\hline 2-Furanmethanol & $\mathrm{A} 18$ & 1663 & $1666[36]$ & $0.015 \pm 0.0028^{a}$ & $0.009 \pm 0.003^{a}$ & $0.018 \pm 0.005^{\mathrm{ab}}$ & $0.025 \pm 0.005^{b}$ & burnt, sweaty, floral [43] \\
\hline Benzyl alcohol & A19 & 1881 & 1879 [45] & $0.006 \pm 0.0021$ & $0.056 \pm 0.027$ & $0.008 \pm 0.004$ & $0.016 \pm 0.003$ & fruity, floral slightly [43] \\
\hline Phenylethyl alcohol & Al10 & 1918 & $1871[35]$ & $0.005 \pm 0.0069$ & $0.01 \pm 0.003$ & $0.007 \pm 0.009$ & $0.011 \pm 0.0005$ & rose [35] \\
\hline Eugenol & Al11 & 2174 & $2171[46]$ & $0.002 \pm 0.001$ & $0.002 \pm 0.002$ & $0.002 \pm 0.002$ & $0.004 \pm 0.005$ & sweaty, clove-like, greeny [46] \\
\hline Glyserin & Al13 & 2329 & $2322[47]$ & nd & $0.065 \pm 0.018$ & nd & $0.024 \pm 0.003$ & sweaty [43] \\
\hline \multicolumn{9}{|c|}{ Aldehydes } \\
\hline 2-Propenal & Ad1 & 866 & $725[39]$ & nd & $0.011 \pm 0.003$ & nd & $0.006 \pm 0.003$ & almond [43] \\
\hline 3-methylbutan-2-ol & Ad2 & 927 & $927[44]$ & $0.002 \pm 0.0008$ & nd & $0.008 \pm 0.004$ & nd & malty, dark chocolate [36] \\
\hline Hexanal & Ad3 & 1085 & $1093[42]$ & $0.011 \pm 0.0066$ & nd & $0.019 \pm 0.00002$ & nd & grassy, tallow, fatty [36] \\
\hline Octanal & Ad4 & 1297 & $1291[45]$ & $0.006 \pm 0.0012$ & nd & nd & nd & fatty, greeny [48] \\
\hline Nonanal & Ad5 & 1392 & $1397[45]$ & $0.019 \pm 0.0048$ & nd & $0.013 \pm 0.005$ & nd & fatty, citrus, greeny [36] \\
\hline Furfural & Ad6 & 1462 & $1471[42]$ & $0.005 \pm 0.0006^{b c}$ & $0.002 \pm 0.0008^{\mathrm{a}}$ & $0.003 \pm 0.0003^{\mathrm{ab}}$ & $0.006 \pm 0.002^{c}$ & sweaty, caramel [43] \\
\hline Benzaldehyde & Ad7 & 1520 & 1521 [49] & nd & nd & $0.004 \pm 0.002$ & $0.007 \pm 0.002$ & almond [43] \\
\hline (E)-2-Nonenal & Ad8 & 1535 & $1542[46]$ & $0.001 \pm 0.00002$ & $0.0004 \pm 0.0002$ & $0.0004 \pm 0.00007$ & $0.0004 \pm 0.0003$ & greeny, fatty [43] \\
\hline Benzene acetaldehyde & Ad9 & 1639 & 1643 [49] & $0.003 \pm 0.001$ & $0.004 \pm 0.0007$ & $0.01 \pm 0.014$ & nd & sweaty [43] \\
\hline 4-Chlorobenzaldehyde & Ad10 & 1770 & & nd & nd & nd & $0.005 \pm 0.003$ & \\
\hline Vanillin & Ad11 & 2577 & $2589[50]$ & $0.007 \pm 0.0012$ & nd & $0.004 \pm 0.001$ & nd & vanilla [36] \\
\hline
\end{tabular}


Table 2. Cont.

\begin{tabular}{|c|c|c|c|c|c|c|c|c|}
\hline \multirow{3}{*}{ Compounds } & \multirow{3}{*}{ Code } & \multirow{3}{*}{$\begin{array}{c}\text { LRI } \\
\text { Experiment }\end{array}$} & \multirow{3}{*}{$\begin{array}{c}\text { LRI } \\
\text { Reference }\end{array}$} & \multicolumn{4}{|c|}{ Relative Peak Area $(\mu \mathrm{g} / \mathrm{kg})$} & \multirow{3}{*}{$\begin{array}{c}\text { Aroma } \\
\text { Description }\end{array}$} \\
\hline & & & & \multicolumn{2}{|c|}{ IPR30 } & \multicolumn{2}{|c|}{ CI } & \\
\hline & & & & Non-Fermented & Fermented & Non-Fermented & Fermented & \\
\hline \multicolumn{9}{|c|}{ Ketones } \\
\hline Butenone & $\mathrm{Kt} 1$ & 952 & $932[41]$ & nd & $0.017 \pm 0.006$ & nd & $0.015 \pm 0.011$ & caramel [40] \\
\hline 4-hydroxybutan-2-one & $\mathrm{Kt} 2$ & 1538 & & nd & $0.002 \pm 0.0007$ & nd & nd & \\
\hline $\begin{array}{l}\text { 1-(1H-pyrrol-2- } \\
\text { yl)ethanone }\end{array}$ & $\mathrm{Kt} 3$ & 1978 & 2017 [39] & $0.001 \pm 0.0002$ & $0.002 \pm 0.0006$ & $0.001 \pm 0.0003$ & $0.002 \pm 0.0006$ & nutty, walnut, bready [36] \\
\hline 2-Pyrrolidinone & $\mathrm{Kt} 4$ & 2056 & $2020[51]$ & $0.001 \pm 0.0001$ & $0.002 \pm 0.0002$ & nd & 0.0004 * & \\
\hline $\begin{array}{l}\text { 6,10,14-Trimethyl-2- } \\
\text { Pentadecanone }\end{array}$ & $\mathrm{Kt5}$ & 2129 & $2110[46]$ & $0.004 \pm 0.0012$ & $0.003 \pm 0.002$ & $0.001 \pm 0.0005$ & $0.002 \pm 0.0005$ & oily, herby [43] \\
\hline \multicolumn{9}{|c|}{ Acids } \\
\hline Acetic acid & As1 & 1450 & $1457[42]$ & $0.058 \pm 0.0206^{b}$ & $0.012 \pm 0.006^{\mathrm{a}}$ & $0.022 \pm 0.008^{a}$ & $0.108 \pm 0.007^{c}$ & sour [36] \\
\hline Hexanoic acid & As2 & 1853 & $1853[42]$ & $0.0077 \pm 0.0014$ & $0.003 \pm 0.0008$ & $0.008 \pm 0.002$ & $0.004 \pm 0.001$ & sweaty [36] \\
\hline Heptanoic acid & As3 & 1960 & 1976 [39] & $0.001 \pm 0.0007$ & nd & nd & nd & \\
\hline 2-ethylhexanoic acid & As4 & 1958 & 1969 [39] & $0.001 \pm 0.0003$ & $0.001 \pm 0.00008$ & $0.002 \pm 0.0007$ & $0.003 \pm 0.001$ & \\
\hline Nonanoic acid & As6 & 2175 & $2185[45]$ & $0.006 \pm 0.0003$ & $0.003 \pm 0.0006$ & $0.005 \pm 0.002$ & $0.008 \pm 0.001$ & greeny, fatty [36] \\
\hline \multicolumn{9}{|c|}{ Esters } \\
\hline Methyl tetradecanoate & Es1 & 2012 & 2014 [42] & $0.02 \pm 0.0151$ & $0.008 \pm 0.0002$ & $0.0004 \pm 0.0001$ & $0.005 \pm 0.0007$ & fatty, waxy, oily [43] \\
\hline Methyl hexadecanoate & Es2 & 2220 & 2203 [52] & $0.003 \pm 0.001$ & $0.047 \pm 0.002$ & $0.001 \pm 0.0004$ & $0.027 \pm 0.005$ & fatty, waxy, oily [43] \\
\hline $\begin{array}{c}\text { Methyl } \\
\text { (E)-octadec-9-enoate }\end{array}$ & Es3 & 2451 & & $0.003 \pm 0.0012$ & $0.027 \pm 0.002$ & nd & $0.009 \pm 0.002$ & fatty, waxy, oily [43] \\
\hline $\begin{array}{c}\text { Methyl (9Z,12Z)-octadeca- } \\
\text { 9,12-dienoate }\end{array}$ & Es4 & 2500 & $2477[52]$ & $0.003 \pm 0.0005$ & $0.022 \pm 0.002$ & nd & $0.008 \pm 0.002$ & fatty, waxy, oily [43] \\
\hline \multicolumn{9}{|c|}{ Benzene } \\
\hline Ethyl benzene & Bz2 & 1126 & $1122[40]$ & $0.003 \pm 0.0005$ & nd & $0.014 \pm 0.006$ & $0.031 \pm 0.015$ & paint [48] \\
\hline Naphtalene & $\mathrm{Bz} 3$ & 1739 & 1718 [49] & $0.003 \pm 0.002$ & $0.006 \pm 0.0007$ & $0.012 \pm 0.008$ & $0.007 \pm 0.001$ & \\
\hline \multicolumn{9}{|c|}{ Terpene } \\
\hline 1R-alpha.-Pinene & $\operatorname{Tr} 1$ & 1032 & 1035 [49] & nd & $0.033 *$ & $0.019^{*}$ & nd & alcoholic, herby [43] \\
\hline Caryophyllene & $\operatorname{Tr} 2$ & 1595 & $1576[42]$ & nd & $0.028 \pm 0.013$ & $0.017 \pm 0.007$ & $0.035 \pm 0.024$ & spicy [43] \\
\hline
\end{tabular}


Table 2. Cont

\begin{tabular}{|c|c|c|c|c|c|c|c|c|}
\hline \multirow{3}{*}{ Compounds } & \multirow{3}{*}{ Code } & \multirow{3}{*}{$\begin{array}{c}\text { LRI } \\
\text { Experiment }\end{array}$} & \multirow{3}{*}{$\begin{array}{c}\text { LRI } \\
\text { Reference }\end{array}$} & \multicolumn{4}{|c|}{ Relative Peak Area ( $\mu \mathrm{g} / \mathrm{kg}$ ) } & \multirow{3}{*}{$\begin{array}{c}\text { Aroma } \\
\text { Description }\end{array}$} \\
\hline & & & & \multicolumn{2}{|c|}{ IPR30 } & \multicolumn{2}{|c|}{ CI } & \\
\hline & & & & Non-Fermented & Fermented & Non-Fermented & Fermented & \\
\hline \multicolumn{9}{|c|}{ Phenol } \\
\hline 2-Methoxyphenol & Fn1 & 1863 & $1877[39]$ & $0.006 \pm 0.0031^{a}$ & $0.014 \pm 0.004^{a}$ & $0.042 \pm 0.014^{b}$ & $0.087 \pm 0.013^{c}$ & smoky, black rice like [48] \\
\hline Phenol & Fn2 & 2009 & $1996[52]$ & $0.024 \pm 0.192$ & $0.008 \pm 0.001$ & $0.003 \pm 0.001$ & $0.012 \pm 0.002$ & phenol 1 [48] \\
\hline 4-methylphenol & Fn3 & 2087 & $2031[44]$ & nd & $0.001 \pm 0.0004$ & nd & nd & phenol, smoky [48] \\
\hline $\begin{array}{l}\text { 4-ethenyl-2- } \\
\text { methoxyphenol }\end{array}$ & Fn4 & 2202 & $2223[41]$ & $0.042 \pm 0.0071^{\mathrm{c}}$ & $0.002 \pm 0.008^{b}$ & $0.01 \pm 0.004^{\mathrm{a}}$ & $0.01 \pm 0.003^{\mathrm{a}}$ & Nutty [53] \\
\hline \multicolumn{9}{|c|}{ Furan } \\
\hline 2-Pentylfuran & Fr1 & 1231 & $1231[44]$ & $0.004 \pm 0.001$ & nd & nd & nd & greeny, beany, buttery [48] \\
\hline 2,3-Dihydro Benzofuran & Fr2 & 2398 & $2391[49]$ & $0.008 \pm 0.0018$ & $0.006 \pm 0.002$ & $0.002 \pm 0.0006$ & nd & \\
\hline \multicolumn{9}{|c|}{ Lactone } \\
\hline Pantolactone & Lk2 & 2038 & $2051[54]$ & $0.003 \pm 0.0018$ & nd & nd & nd & cotton candy [36] \\
\hline \multicolumn{9}{|c|}{ Thiazole } \\
\hline Benzothiazole & $\mathrm{Tz}$ & 1964 & 1948 [49] & $0.002 \pm 0.0005$ & $0.003 \pm 0.002$ & nd & $0.001 *$ & gasoline, rubbery [48] \\
\hline \multicolumn{9}{|c|}{ Pyridine } \\
\hline 3-methylpyridine & Prd & 1300 & & nd & $0.024 \pm 0.018$ & nd & nd & greeny [43] \\
\hline \multicolumn{9}{|c|}{ Pyrazine } \\
\hline 2-methylpyrazine & Prz & 1267 & $1273[36]$ & $0.002 \pm 0.0005$ & nd & nd & nd & roasty, nutty [55] \\
\hline
\end{tabular}

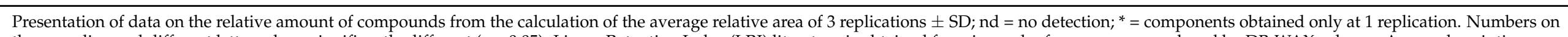

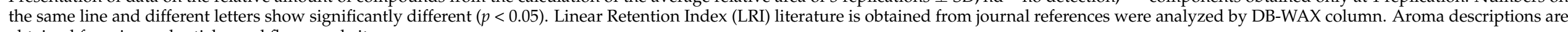
obtained from journal articles and flavor website. 
Sample 534 has the highest elevation value $\left(95^{\circ}\right.$ ) because the benchmark (control) was derived from white rice RB, followed by sample 375 (IPR30NF) with an elevation value of $40-50^{\circ}$ and sample 298 (IPR30F) with an elevation of $20-30^{\circ}$. As they were located in the same dimension, sample 375 has similar sensory characteristics to sample 298 as both samples were IPR30 RB. Furthermore, samples 192 (CIF) and 736 (CINF) were both located in the same dimension with an elevation value of $30^{\circ}$ and $40^{\circ}$, respectively. Both samples have similar characteristics as they are similar varieties of CI RB.

Panelists could not accept or dislike $(n=26)$ sample 534 (benchmark) because of its taste (bland, pungent, rancid, and bitter) and aroma (bland, pungent, bitter rancid, and sour). Conversely, panelists liked and accepted samples 298 (IPR30F) ( $\mathrm{n}=26$ and 23); 375 (IPR30NF) ( $\mathrm{n}=27$ and 26); 192 (CIF) ( $\mathrm{n}=28$ and 30); and 634 (CINF) $(\mathrm{n}=24$ and 28) as these samples had the dominant and accepted taste (sweet and savory) and aroma attributes (milk, sticky rice, and fresh). These results were consistent with data in preference mapping (Figure 3b). Positions of samples 192 (CIF), 736 (CINF), 298 (IPR30F) and 375 (IPR30NF) were at different poles and colors (blue and degraded blue) when compared to sample 534 (benchmark or control) at the red pole. Samples at the blue pole had been liked, accepted, and preferred by the panelists, while the samples at the red pole were not liked or preferred.

In this study, SSF is shown to increase the bioactivity of rice bran, similar to results shown with our previous study (15-17). Other researchers have also shown the same phenomena (10-13). SSF is one strategy to improve the sensory profile of rice bran, although future studies are needed to expand the study with a greater number of cultivars of rice. Fermentation can increase the functional properties of RB, in order to use RB for functional ingredients, and the creation of novel, functional food for prolonging healthy life.

\section{Materials and Methods}

\subsection{Chemicals and Reagents}

Methanol, Folin Ciocalteu's phenol reagent, gallic acid, 2,2-diphenyl-1-picrylhydrazyl (DPPH), and 2,4,6-trimethylpyridine were purchased from Sigma-Aldrich Co. (Saint Louis, MO, USA). R. oligosporus was from the Indonesian Culture Collection, Research Center for Biology, the Indonesian Institute of Science, Cibinong Indonesia. Black CI rice (Bogor, West Java, Indonesia) and IPR30 rice was from the Indonesian Center for Rice Research, Indonesian Agency for Agricultural Research and Development, Ministry of Agriculture, Subang, West Java, Indonesia.

\subsection{Sample Preparation}

Two types of RB were used in this study. Black CI continued with the milling process using a Rice Machine-THU (Satake, Japan) to obtain brown rice. White IPR30 was in brown rice from. Two types of brown rice were processed by mini rice mill processing (Satake Grain Testing Mill, Hiroshima, Japan); then the RB was sieved as described previously [15]. $R$. oligosporus were maintained on potato dextrose agar media. The culture and fermentation process had been prepared as described previously [15]. For TPC and antioxidant analysis, fermented and non-fermented RB were extracted as described previously [13] with some modifications [15]. Fermented and non-fermented RB were extracted with methanol (HPLC grade) at 1:10 $(v / v)$ by shaking in an orbital shaker at $30{ }^{\circ} \mathrm{C}(150 \mathrm{rpm})$ for $3 \mathrm{~h}$ and then sonicated for $10 \mathrm{~min}$. The methanol-extracted samples were centrifuged at $7826 \times g$ for $10 \mathrm{~min}$, and the supernatant was filtered. The filtrates (methanol extract) were stored at $-20{ }^{\circ} \mathrm{C}$ until analysis. After the harvest, the RB was mixed with distilled water and centrifuged at $7826 \times g$ for $15 \mathrm{~min}$; then the suspension was filtered and lyophilized.

\subsection{Analysis of Total Phenolic Content (TPC) and Antioxidant Activity}

TPC and antioxidant activity (2,2-diphenyl-1-picrylhydrazyl, DPPH assay) were determined by microplate methods described by [46] with slight modification. Twenty microliters of each sample were transferred into a 96-well plate then reacted with $100 \mu \mathrm{L}$ of diluted Folin-Ciocalteu's for TPC analysis and reacted with $180-\mu \mathrm{L}$ working solution 
DPPH for antioxidant activity analysis. DPPH RSA values are expressed as mg TE per $100 \mathrm{~g}$ of sample DB.

\subsection{GC-MS Analysis}

Volatile compounds from two types of fermented and non-fermented RB (CI and IPR30) were extracted using the headspace-solid phase microextraction (HS-SPME) attached with divinylbenzene/carboxen/polydimethylsiloxane (DVB/CAR/PDMS) StableFlex fiber of 50-/30- $\mu \mathrm{m}$ thickness and 2-cm length (Supelco, Inc., Bellefonte, PA, USA) following Zeng et al. [20] with a slight modification. Three grams of sample and $0.4 \mu \mathrm{L}$ $0.01 \%$ internal standard (IS) 2,4,6-trimethylpyridine (Sigma-Aldrich, Saint Louis, MO, USA) were transferred into a 22-mL headspace vial and covered with a silicone septum. Then the extraction fiber was inserted into the vial to be extracted in a water bath at a temperature of $80^{\circ} \mathrm{C}$ for $30 \mathrm{~min}$. After extraction, the fiber was removed from the vial and fed into the GC-MS injector at $250{ }^{\circ} \mathrm{C}$ hot desorption for $5 \mathrm{~min}$. Every peak area in the chromatograms was standardized by the resulting area for the TMP peak. The GC-MS analysis was determined with GC-MS Agilent 7890A-5975C (Agilent Technologies, Palo Alto, CA, USA). Chromatographic separation was performed with an DB-WAX capillary column ( $30 \mathrm{~m} \times 0.25 \mathrm{~mm}$ i.d. and $0.25-\mu \mathrm{m}$ film thickness, Agilent, J \& W) under the following instrumental conditions: helium as carrier gas at a constant flow of $0.8 \mathrm{~mL} / \mathrm{min}$, pressure of $60 \mathrm{kPa}$, electron ionization voltage of $70 \mathrm{eV}$, injector with mode splits at temperature $250{ }^{\circ} \mathrm{C}$, and the oven initial temperature of $40{ }^{\circ} \mathrm{C}$ for $2 \mathrm{~min}$, which was increased to $230{ }^{\circ} \mathrm{C}$ with $3{ }^{\circ} \mathrm{C} / \mathrm{min}$ rate. Identification of the volatile components was based on a comparison of their mass spectra with those present in the NIST 2.0 database and confirmed by comparing their retention indexes with the published references [56]. Linear retention indexes (LRI) were calculated using the retention data of linear alkanes (C8-C30, Fluka) solution in n-hexane [20]. Relative amounts of volatiles were calculated by comparing their peak areas with IS peak area, whereby $5 \mu \mathrm{L}$ IS are equal with $50 \mathrm{~g}$ sample. Data were analyzed as a mean of three replications.

\subsection{Sensory Profile Analysis}

Sensory profile was analyzed using projective mapping with 75 naïve panelists (based on their interest and availability) to evaluate the color, taste, flavor, and texture of the samples [52]. This study was based on ISO 13299:2016 Sensory Analysis-Methodology-General Guidance to establish a sensory profile. All panelists supplied informed consent before the examination. The preference mapping was used to evaluate which sample was preferable by the panelist as well as indicate the attribute related to preference [57]. Five samples with trivial code were used in this study: (1) 534 Benchmark (control)-a white rice bran derived from Ciherang cultivar, (2) 192 CI fermented RB, (3) 736 CI non-fermented RB, (4) 298 IPR30 fermented RB, and (5) 375 IPR30 non-fermented RB, respectively. Samples were prepared by the following procedure: $0.5 \mathrm{~g}$ of samples were mixed with $2.0 \mathrm{~g}$ commercial cereal and added to $15 \mathrm{~mL}$ of plain milk, then served to panelists. The panelists were free to place the sample in the $60 \times 60 \mathrm{~cm}$ paper, based on their preference and similarity/dissimilarity of the sample with the benchmark.

\subsection{Statistical Analysis}

All data are reported as the mean and standard deviation. One-way analysis of variance using SPSS version 22.0 (SPSS, Inc., Chicago, IL, USA) was performed by two-way analysis followed by Duncan's multiple range test for TPC and antioxidant parameters. The level of $p<0.05$ was considered to indicate a significant difference between the means of groups. The preference mapping was analyzed by using multiple factor analysis (MFA) with Software R v.3.6.0. The MFA generates two figures simultaneously, which are Hierarchical Analysis and preference mapping. The PCA analysis was done by XLStat 2019 (New York, NY, USA). 


\section{Conclusions}

In conclusion, this study analyzed and compared the TPC, antioxidant activities, volatile compounds, and sensory profiles of two RB cultivars before and after fermentation. It was observed that fermentation using $R$. oligosporus enhanced TPC and antioxidant activity of RB. Regarding antioxidant activity, future studies are needed to use another method. PCA plot analysis was located in different dimension; this means that the fermentation process can affect and differentiate the volatile compounds of RB, sensory profile, and the acceptance of the samples. The fermentation may amplify active compounds of RB and has the potential to produce functional ingredients for human health promotion.

Author Contributions: Conceptualilization, A., W.D. and D.D.H.; Investigation, A., A.N., N.T.I.R., A.O. and R.M.A.; Supervision, A., W.D., R.M.A., D.D.H., B.K. and S.B.; Writing-original draft, A.; Writing-review \& editing, W.D., D.D.H., B.K., S.B. and H.S. All authors have read and agreed to the published version of the manuscript.

Funding: This research was funded by Ministry of Research and Technology/the National Research and Innovation Agency of Republic Indonesia with grant number 1226/LL3/PG/2021.

Institutional Review Board Statement: Not applicable.

Informed Consent Statement: Not applicable.

Data Availability Statement: Data are contained within the manuscript.

Acknowledgments: The authors gratefully acknowledge for technical assistance of Mbak Arie.

Conflicts of Interest: The authors declare no conflict of interest.

\section{References}

1. Gutaker, R.M.; Groen, S.C.; Bellis, E.S.; Choi, J.Y.; Pires, I.S.; Bocinsky, R.K.; Slayton, E.R.; Wilkins, O.; Castillo, C.C.; Negrão, S.; et al. Genomic history and ecology of the geographic spread of rice. Nat. Plants 2020, 5, 492-502. [CrossRef]

2. Badan Pusat Statistik (BPS). Luas Panen dan Produksi Padi di Indonesia. Available online: https://www.bps.go.id/ pressrelease/2020/02/04/1752/luas-panen-dan-produksi-padi-pada-tahun-2019-mengalami-penurunan-dibandingkantahun-2018-masing-masing-sebesar-6-15-dan-7-76-persen.html (accessed on 20 January 2021).

3. Ardiansyah; Shirakawa, H.; Koseki, T.; Ohinata, K.; Hashizume, K.; Komai, M. Rice bran fractions improve blood pressure, lipid profile, and glucose metabolism in stroke-prone spontaneously hypertensive rats. J. Agric. Food Chem. 2006, 54, 1914-1920. [CrossRef] [PubMed]

4. Oliveira, M.S.; Feddern, V.; Kupski, L.; Cipolatti, E.P.; Badiale-Furlong, E.; de Souza-Soare, L.A. Changes in lipid, fatty acids and phospholipids composition of whole rice bran after solid-state fungal fermentation. Biores. Tech. 2011, 102, 8335-8338. [CrossRef] [PubMed]

5. Cicero, A.F.; Gaddi, A. Rice bran oil and $\gamma$-oryzanol in the treatment of hyperlipoproteinaemias and other conditions. Phytother. Res. 2001, 15, 277-289. [CrossRef]

6. Jung, E.H.; Ha, T.Y.; Hwang, I.K. Anti-hyperglycemic and antioxidative activities of phenolic acid concentrates of rice bran and hydroxycinnamic acids in cell assays. Korean J. Food Nutr. 2010, 23, 233-239.

7. Moure, A.; Cruz, J.M.; Franco, D.; Domínguez, J.M.; Sineiro, J.; Domínguez, H.; Núñez, M.J.; Parajó, J.C. Natural antioxidants from residual sources. Food Chem. 2001, 72, 145-171. [CrossRef]

8. Oliveira, M.D.S.; Cipolatti, E.P.; Furlong, E.B.; Soares, L.S. Phenolic compounds and antioxidant activity in fermented rice (Oryza sativa) bran. Ciênc. Tecnol. Aliment. Camp. 2012, 32, 531-537. [CrossRef]

9. Shahidi, F.; Naczk, M. Phenolic in Food and Nutraceutical; CRC Press: Boca Raton, FL, USA, 2004; pp. 17-82.

10. Schmidt, C.G.; Gonçalves, L.M.; Prietto, L.; Hackbart, H.S.; Furlong, E.B. Antioxidant activity and enzyme inhibition of phenolic acids from fermented rice bran with fungus Rizhopus oryzae. Food Chem. 2014, 146, 371-377. [CrossRef] [PubMed]

11. Oliveira, M.S.; Feddern, V.; Kupski, L.; Cipolatti, E.P.; Badiale-Furlong, E.; Souza-Soares, L.A. Physico-chemical characterization of fermented rice bran biomass-Caracterización fisico-química de la biomasa del salvado de arroz fermentado. CyTA-J. Food 2010, 8, 229-236. [CrossRef]

12. Kim, D.; Dong Han, G. Fermented rice bran attenuates oxidative stress. In Wheat and Rice in Disease Prevention and Health: Benefits, Risks and Mechanisms of Whole Grains in Health Promotion; Watson, R.S., Preedy, V.R., Zibadi, S., Eds.; Academic Press: San Diego, CA, USA, 2014; pp. 467-480.

13. Razak, D.L.A.; Rashid, N.Y.A.; Jamaluddin, A.; Sharifudin, S.A.; Long, K. Enhancement of phenolic acid content and antioxidant activity of rice bran fermented with Rhizopus oligosporus and Monascus purpureus. Biocat. Agric. Biotech. 2015, 4, 33-38. [CrossRef]

14. Bhanja, T.; Rout, S.; Banerjee, R.; Bhattacharyya, B.C. Studies on the performance of a new bioreactor for improving antioxidant potential of rice. LWT 2008, 41, 1459-1465. [CrossRef] 
15. Ardiansyah; David, W.; Handoko, D.D.; Kusbiantoro, B.; Budijanto, S.; Shirakawa, H. Fermented rice bran extract improves blood pressure and glucose in stroke-prone spontaneously hypertensive rats. Nutr. Food Sci. 2019, 49, 844-853. [CrossRef]

16. Noviasari, S.; Kusnandar, F.; Setiyono, A.; Budi, F.S.; Budijanto, S. Profile of phenolic compounds, DPPH-scavenging and anti $\alpha$-amylase activity of black rice bran fermented with Rhizopus oligosporus. Pertanika J. Trop. Agric. Sci. 2019, 42, 489-501.

17. Zulfafamy, K.E.; Ardiansyah; Budijanto, S. Antioxidative properties and cytotoxic activity against colon cancer cell WiDr of rhizopus oryzae and rhizopus oligosporus-fermented black rice bran extract. Cur. Res. Nutr. Food Sci. 2018, 6, 23-34. [CrossRef]

18. Mitsuda, H.; Yasumoto, K.; Iwami, K. Analysis of volatile components in rice bran. Agric. Biol. Chem. 1968, 32, 453-458. [CrossRef]

19. Tsugita, T.; Kurata, T.; Fujimaki, M. Volatile components in the steam distillate of rice bran: Identification of neutral and basic compounds. Agric. Biol. Chem. 1978, 42, 643-651. [CrossRef]

20. Zeng, M.; Zhang, L.; He, Z.; Qin, F.; Tang, X.; Huang, X.; Qu, H.; Chen, J. Determination of flavor components of rice bran by GC-MS and chemometrics. Food Anal. Methods 2012, 4, 539-545. [CrossRef]

21. Sukhontara, S.; Theerakulkait, C.; Miyazawa, M. Characterization of volatile aroma compounds from red and black rice bran. J. Oleo Sci. 2009, 58, 155-161. [CrossRef] [PubMed]

22. Arsa, S.; Theerakulkait, C. Preparation, aroma characteristics and volatile compounds of flavorings from enzymatic hydrolyzed rice bran protein concentrate. J. Sci. Food Agric. 2018, 98, 4479-4487. [CrossRef]

23. Lee, S.M.; Hwang, Y.R.; Kim, M.S.; Chung, M.S.; Kim, Y.S. Comparison of volatile and nonvolatile compounds in rice fermented by different lactic acid bacteria. Molecules 2019, 24, 1183. [CrossRef]

24. Salmerón, I.; Loeza-Serrano, S.; Peréz-Vega, S.; Pandiella, S.S. Headspace gas chromatography (HS-GC) analysis of imperative flavor compounds in lactobacilli-fermented barley and malt substrates. Food Sci. Biotechnol. 2015, 24, 1363-1371. [CrossRef]

25. Lee, S.M.; Oh, J.; Hurh, B.S.; Jeong, G.H.; Shin, Y.G.; Kim, Y.S. Volatile compounds produced by Lactobacillus paracasei during oat fermentation. J. Food Sci. 2016, 81, C2915-C2922. [CrossRef]

26. Hopfer, H.; Heymann, H. A Summary of projective mapping observations-the effect of replicates and shape, and individual performance measurements. Food Qual. Prefer. 2013, 28, 164-181. [CrossRef]

27. Vattem, D.; Shetty, K. Solid-state production of phenolic antioxidants from Cranberry pomace by R. oligosporus. Food Biotechnol. 2002, 16, 189-210. [CrossRef]

28. Hur, S.J.; Lee, S.Y.; kim, Y.C.; Choi, I.; Kim, G.B. Effect of fermentation on the antioxidant activity in plant-based foods. Food Chem. 2014, 160, 346-536. [CrossRef]

29. Webber, D.M.; Hettiarachchy, N.S.; Li, R.; Horax, R.; Theivendran, S. Phenolic profile and antioxidant activity of extracts prepared from fermented heat-stabilized defatted rice bran. J. Food Sci. 2014, 79, H2383-H2391. [CrossRef]

30. Bocharova, O.; Reshta, S.; Eshtokin, V. Toluene and benzyl alcohol formation in fruit juice containing benzoates. J. Food Process. Pres. 2016, 41, e13054. [CrossRef]

31. Tang, H.; Ma, J.K.; Chen, L.; Jiang, L.W.; Xie, J.; Li, P.; He, J. GC-MS characterization of volatile flavor compounds in stinky tofu brine by optimization of headspace solid-phase microextraction condition. Molecules 2018, 23, 3155. [CrossRef]

32. Lombion, S.; Comte, A.; Tatu, L.; Brand, G.; Moulin, T.; Millot, J.L. Pattern of cerebral activation during olfactory and trigeminal stimulations. Hum. Brain Mapp. 2009, 30, 821-828. [CrossRef]

33. Takahashi, T.; Mizui, K.; Miyazawa, M. Volatile compounds with characteristic odour in moso-bamboo stems (Phyllostachys pubescens Mazel ex Houz. De ehaie). Phytochem. Anal. 2010, 21, 489-495. [CrossRef] [PubMed]

34. Kesselmeier, J.; Staudt, M. Biogenic volatile organic compounds (VOC): An overview on emission, physiologyand ecology. J. Atmos. Chem. 1999, 33, 23-88. [CrossRef]

35. Hang, M.Q.; Zou, Q.Q.; Tian, H.Y.; Sun, B.G.; Chen, H.T. Analysis of volatile components from Dictyophora rubrovolota Zang, ji et liou. Procedia Eng. 2012, 37, 240-249. [CrossRef]

36. Thammarat, P.; Kulsing, C.; Wongravee, K.; Leepipatpiboon, N.; Nhujak, T. Identification of volatile compounds and selection of discriminant markers for elephant dung coffee using static headspace gas chromatography-mass spectrometry and chemometrics. Molecules 2018, 23, 1910. [CrossRef]

37. Briant, R.J.; McClung, M.A. Volatile profiles of aromatic and non-aromatic rice cultivars using SPME/GC-MS. Food Chem. 2011, 124, 501-513. [CrossRef]

38. Lopes, D.; Strobi, H.; Kolodziejczyk, P. 14-Methylpentadecanone-15-Lactone (Muscolide): A new macrocyclic lactone from the oil of Angelica archangelica L. Chem. Biodivers. 2004, 12, 1880-1887. [CrossRef]

39. Welke, J.E.; Manfroi, V.; Zanus, M.; Marcelo, L.; Zini, C.A. Characterization of the volatile profile of Brazilian Merlot wines through comprehensive two dimensional gas chromatography time-of-flight mass spectrometric detection. J. Chromatogr. A 2012, 1226, 124-139. [CrossRef]

40. Osorio, C.; Duque, C.; Suarez, M.; Salamanca, L.E.; Uruena, F. Free, glycosidically bound, and phosphate bound flavor constituents of badea (Passiflora quadrangularis) fruit pulp. J. Sep. Sci. 2002, 25, 147-154. [CrossRef]

41. Culleré, L.; Escudero, A.; Cacho, J.; Ferreira, V. Gas chromatography-olfactometry and chemical quantitative study of the aroma of six premium quality spanish aged red wines. J. Agric. Food Chem. 2004, 52, 1653-1660. [CrossRef]

42. Tamura, H.; Boonbumrung, S.; Yoshizawa, T.; Varanyanond, W. Volatile components of the essential oils in the pulp of four yellow yangoes (Mangifera indica L.) in Thailand. Food Sci. Technol. Res. 2000, 6, 68-73. [CrossRef]

43. The Good Scents Company. Available online: http://www.thegoodscentscompany.com/ (accessed on 4 February 2021). 
44. Liu, X.S.; Liu, J.B.; Yang, Z.M.; Song, H.L.; Liu, Y.; Zou, T.T. Aroma-active compounds in jinhua ham produced with different fermentation periods. Molecules 2014, 19, 19097-19113. [CrossRef]

45. Goodner, K. Practical retention index models of OV-101, DB-1, DB-5, and DB-Wax for flavor and fragrance compounds. LWT 2008, 41, 951-958. [CrossRef]

46. Bobo-Garcia, G.; Daidov-Pardo, G.; Arroqui, C.; Virseda, P.; Marin-Arroyo, M.R.; Navarro, M. Intra-laboratory validation of microplate methods for total phenolic content and antioxidant activity on polyphenolic extracts, and comparison with conventional spectrophotometric methods. J. Sci. Food Agric. 2014, 95, 204-209. [CrossRef] [PubMed]

47. Pozo-Bayón, M.A.; Ruíz-Rodríguez, A.; Pernin, K.; Cayot, N. Influence of eggs on the aroma composition of a sponge cake and on the aroma release in model studies on flavored sponge cakes. J. Agric. Food Chem. 2007, 55, 1418-1426. [CrossRef]

48. Flavornet. Available online: http:/ / flavornet.org/flavornet.html (accessed on 3 January 2021).

49. $\mathrm{Wu}, \mathrm{S} . ; \mathrm{Xu}, \mathrm{T}$; Akoh, C.C. Effect of roasting on the volatile constituents of Trichosanthes kirilowii seeds. J. Food Drug Anal. 2014, 22, 310-317. [CrossRef]

50. Paravisini, L.; Prot, A.; Gouttefangeas, C.; Moretton, C.; Nigay, H.; Dacremont, C.; Guichard, E. Characterisation of the volatile fraction of aromatic caramel using heart-cutting multidimensional gas chromatography. Food Chem. 2015, 167, 281-289. [CrossRef]

51. Kim, T.H.; Shin, J.H.; Baek, H.H.; Lee, H.J. Volatile flavour compounds in suspension culture of Agastache rugosa Kuntze (Korean mint). J. Sci. Food Agric. 2001, 81, 569-575. [CrossRef]

52. Delholm, C.; Brockhoff, P.B.; Meinert, L.; Aaslyng, M.D.; Bredie, W.I. Rapid descriptive sensory methods-comparison of free multiple sorting, partial napping, napping, flash profiling and coventional profiling. Food Qual. Prefer. 2012, 26, 267-277. [CrossRef]

53. Yang, D.S.; Lee, K.S.; Jeong, O.Y.; Kim, K.J.; Kays, S.J. Characterization of volatile aroma compunds in cooked black rice. J. Agric. Food Chem. 2008, 56, 235-240. [CrossRef]

54. Chinnici, F.; Guerrero, E.D.; Sonni, F.; Natali, N.; Marín, R.N.; Riponi, C. Gas chromatography-mass spectrometry (GC-MS) characterization of volatile compounds in quality vinegars with protected european geographical indication. J. Agric. Food Chem. 2009, 57, 4784-4792. [CrossRef] [PubMed]

55. Shetty, K.; Paliyath, G.; Pometto, A.; Levin, R.E. Food Biotechnology, 2nd ed.; CRC Taylor \& Francis: New York, NY, USA, 2006; pp. 407-442.

56. Lee, S.M.; Lim, H.J.; Chang, J.W.; Hurh, B.S.; Kim, Y.S. Investigation on the formations of volatile compounds, fatty acids, and $\mathrm{\gamma}$-lactones in white and brown rice during fermentation. Food Chem. 2018, 269, 347-354. [CrossRef] [PubMed]

57. Greenhoff, K.; MacFie, H. Preference mapping in practice. In Measurement of Food Preferences; Springer: Berlin/Heidelberg, Germany, 1994; pp. 137-166. 